\title{
DIETARY EFFECT ON FRY PRODUCTION AND GROWTH PERFORMANCE OF SAILFIN MOLLY, POECILIA LATIPINNA, IN SALT WATER
}

\author{
Kumaravel P. KUMARAGURU VASAGAM 2*, Annaian SHANMUGAM ${ }^{1}$, \\ and Santhanam RAJAGOPAL ${ }^{1}$ \\ ${ }^{1}$ Center of Advanced Study in Marine Biology, Annamalai University, Tamilnadu, India \\ ${ }^{2}$ Integrated Aquaculture International (USA), Department of Fisheries, Negara Brunei Darussalam
}

Kumaraguru vasagam K.P., Shanmugam A., Rajagopal S. 2007. Dietary effect on fry production and growth performance of sailfin molly, Poecilia latipinna, in salt water. Acta Ichthyol. Piscat. 37 (1): 29-35.

\begin{abstract}
Background. The viviparous sailfin molly, Poecilia latipinna (Lesueur, 1821), is a popular ornamental fish that thrives in a wide range of salinities. It is well known that salt water of intermediate salinity $(25 \%)$ is suitable for mollies, especially for healthy breeding. Nutrition has been recognized to have a profound effect upon gonadal development and fry production in fish. Hence, the present work was carried out to evaluate the suitability of different practical diets, such as oyster meat, live tubificid worms, and formulated feed, on fry production, gestation period, and growth performance of $P$. latipinna in salt water.

Materials and Methods. A trial was conducted on P. latipinna in salt water (25\%o salinity) to evaluate the suitability of oyster meat, live tubificid worms, formulated feed, and a mixture of these three diets, on breeding and growth. Results. Irrespective of diet, the gestation period was consistently 28 days. Maximum fry yield (460 fry) and better growth performance was obtained in brooders and juveniles respectively fed mixed diet. A positive correlation existed between the loss of weight due to spawning in the brooders and fry production in all dietary treatments. Among the dietary treatments there was a significant difference $(P<0.005)$ in growth performance parameters, such as weight gain $[\mathrm{g}]$, food conversion ratio (FCR), and specific growth rate (SGR).

Conclusion. Among the four dietary treatments, the mixed diet performed well in both breeding and rearing experiments. Hence in commercial breeding units, mixed feeding regimen could be adopted with mollies in salt water.
\end{abstract}

Keywords: Poecilia latipinna, salinity, breeding, growth, feed

\section{INTRODUCTION}

Three of the top 10 species of ornamental fishes imported into the USA are viviparous cyprinodontids of the family Poeciliidae. In India poeciliids account for fifty percent of the market share in ornamental fishes (Mahapatra et al. 2000, Ramachandran 2002). The livebearing Poecilia latipinna (Lesueur), commonly known, as the sailfin molly is a popular ornamental fish bred commercially in many countries, including tropical India (Ghosh et al. 2003, Ramachandran 2002). In view of its hardy nature and ease of breeding in simple holding facilities, this fish is highly recommended for beginners in ornamental fish breeding and, especially in India, for women's self-help groups trained in entrepreneurship (authors' unpublished observation).

Although this fish thrives in a wide range of salinities $(0-94.6 \%)$, pure freshwater is not suitable, especially for healthy breeding (Kristensen 1969, Whitern 1983, Nordlie and Mirandi 1996, Haney and Walsh 2003, Kumaraguru vasagam et al. 2005). Wild fishes of the genus Poecilia (guppies and mollies) are generally found in fresh- and brackish water bodies such as streams, rivers, ponds, and estuaries (Nordlie et al. 1992). Salt is conventionally added to molly tanks to induce breeding (Whitern 1983). Use of mollies in breakthrough in marine aquaria (a process to augment nitrifying bacteria initially) has become common.

Osmoregulation is an energy demanding metabolic process. Iso-osmotic salinities minimize osmoregulatory stress and associated energy costs, thereby increasing the energy available for growth and survival (Sampaio and Bianchini 2002). This is evidenced in P. latipinna by better breeding and growth performance at 25\% (Kumaraguru vasagam et al. 2005). Euryhaline marine fish larvae also show better growth and survival in iso-osmotic salinities (Tandler and Helps 1985, Mihelakakis and Kitjima 1994).

Nutrition has a profound effect upon gonadal development and fry production in fish (Watanabe 1985). Fry production is generally positively related to body size,

\footnotetext{
${ }^{*}$ Correspondence: Dr. K.P. Kumaraguru vasagam, Pusat Perkembangan Induk, Ladang Ikan Serasa, Jalan Pantai Serasa, Jabatan Perikanan, Kementerian Perindustrias Dan, Sumber- Sumber Utama, Negara Brunei Darussalam, phone: 00673 8788809, e-mail: drvasagamguru@yahoo.co.in
} 
and improved food availability and higher temperatures, which produce faster growth, result in larger and more fecund individuals (Wootton 1973, Hislop et al. 1978, Townsend and Wootton 1984, Springate et al. 1985). Large commercial producers of aquarium fish in Singapore emphasize the importance of regular supplementation of formulated feeds with live feed, usually as Daphnia sp. or tubificid worms (Fernando et al. 1991). Indian aquarists use only farm-made feeds such as steamed vermicelli, rice bran, wheat flour, and wet mash containing ragi flour, tapioca flour, fishmeal, and plant oil meals in unbalanced proportions (unpublished observation). Kruger et al. (2001a) obtained a large number of fry when poeciliid $X$. helleri were maintained on a flake diet supplemented with live Daphnia.

There has been no systematic study of the influence of diet (both formulated and natural diet) on breeding and growth performance of $P$. latipinna, especially in 25-\%o salt water, which yields maximum fry number and fast growth (Kumaraguru vasagam et al. 2005). Hence, the present work was carried out to evaluate the suitability of different practical diets (oyster meat, live tubificid worms and formulated feed) on fry production, gestation period and growth performance of $P$. latipinna in salt water.

\section{MATERIALS AND METHODS}

The breeding trial used five-week-old P. latipinna, obtained from breeders, maintained at $25-\%$ salinity during previous trials in the same laboratory. To avoid sizeand age differences, fry spawned on the same day were selected. These fish were stocked into a 4000-L concrete tank and initially fed commercial feed (Hitachi, Singapore) for a week, after which four batches of 60 fry were randomly stocked into four 1000-L circular fibreglass tanks at $25 \%$. Each batch received one of the fol- lowing dietary treatments: formulated feed, oyster meat, live tubificid worms, and a mixture of these three diets (in alternate rations of the day). The fish were reared to maturity and observations made on survival and behaviour. The growth trial used the same diets and was conducted with the last clutch of fry from the breeding trial.

Photoperiod was set to $12: 12$ light : dark. Continuous aeration was provided from an aquarium air compressor through air stones. Half the tank volume of water was exchanged daily. Dissolved oxygen, $\mathrm{pH}$, nitrite-nitrogen, and ammonia-nitrogen concentrations were measured weekly according to the methods of Strickland and Parsons (1972). Salinity was measured with a refractometer (Atago, Japan) after water exchange. All the water quality parameters remained constant throughout the experiment for all the dietary treatments: salinity of $25 \%$, temperature of $25-28.5^{\circ} \mathrm{C}, \mathrm{pH}$ of $7.4-8.2$, dissolved oxygen $>5.67 \mathrm{mg} \cdot \mathrm{L}^{-1}$, total ammonia-nitrogen of $0.06-0.09$ $\mathrm{mg} \cdot \mathrm{L}^{-1}$, and nitrite-nitrogen of $0.09-0.18 \mathrm{mg} \cdot \mathrm{L}^{-1}$.

A dry pelleted feed was formulated to contain $451 \mathrm{~g} \cdot \mathrm{kg}^{-1}$ crude protein and $61 \mathrm{~g} \cdot \mathrm{kg}^{-1}$ crude lipid with conventional feed ingredients (Table 1) as recommended by Kruger et al. (2001b). Feed was prepared according to De Silva and Anderson (1995). All the finely ground $(<250 \mu \mathrm{m})$ ingredients were mixed and made into dough like consistency by adding water. The dough was steamed in autoclave at $100^{\circ} \mathrm{C}$ for 10 minutes, then it was cooled and hand mixed thoroughly after dispersing fish oil and vitamin mix. Finally the dough was pelletized through a $2-\mathrm{mm}$ die and then dried overnight at $55^{\circ} \mathrm{C}$ using a hot air oven. After drying, the pellets were stored at $-5^{\circ} \mathrm{C}$ until use. Live tubificid worms were collected from the kitchen sewage discharge point at our institute hostel and thoroughly washed in running tap water before feeding. Live oysters were collected from the Vellar estuary and their meat minced

Table 1

Composition of the formulated feed

\begin{tabular}{lc}
\hline Ingredient & Contents $\left[\mathrm{g} \cdot \mathrm{kg}^{-1}\right.$ dry weight $]$ \\
\hline Fish meal ${ }^{1}$ & 300 \\
Soy bean meal & 501 \\
Wheat flour $^{2}$ & 146 \\
Fish oil $^{2}$ & 20 \\
Soy lecithin $^{3}$ & 10 \\
Vitamin and mineral mix $^{4}$ & 10 \\
Binder $^{5}$ & 10 \\
Mould inhibitor $^{6}$ & 1.5 \\
Antioxident $^{7}$ & 1.5 \\
\hline
\end{tabular}

${ }^{1}$ Full fat sardine meal prepared in our laboratory; ${ }^{2}$ Sardine body oil obtained from Coastal Aquatic Proteins, Mangalore, India; ${ }^{3}$ Standard fluid soy lecithin (63\% phospholipid), obtained from Central Soya, Fort Wayne, Indiana, United States of America; 487912 IU Vitamin A acetate, 2200 IU cholecalciferol (D3), 550 IU tocopheryl acetate (E), 22 mg menadione, 189 $\mathrm{mg}$ D-calcium pantothenate, $77.6 \mathrm{mg}$ pyridoxine $\mathrm{HCl}, 66 \mathrm{mg}$ riboflavin, $330 \mathrm{mg}$ niacin, $22 \mathrm{mg}$ folic acid, $73.9 \mathrm{mg}$ thiamine mononitrate, $2.2 \mathrm{mg}$ biotin, $0.1 \mathrm{mg}$ cyanocobalamin (B12), $220 \mathrm{mg}$ inositol, $2.8 \mathrm{mg} \mathrm{Cu}, 39.1 \mathrm{mg} \mathrm{Fe}, 107.3 \mathrm{mg} \mathrm{Zn,} 41.1 \mathrm{mg}$ Mn, $1674 \mathrm{mg} \mathrm{K}, 10 \mathrm{mg} \mathrm{I}, 0.5 \mathrm{mg}$ Co and $0.4 \mathrm{mg} \mathrm{Se} ;{ }^{5}$ Carboxymethylcellulose (CMC); ${ }^{6}$ Endoxy dry (butylated hydroxyl anisole), Kemin Nutritional Technologies, India; ${ }^{7}$ Mycocurb (propionic acid), Kemin Nutritional Technologies, India. 
and cleaned in running tap water. A mixed dietary treatment was offered by feeding the fishes with each one of the above said diets in respective three rations of the day. All fish (brood stock and fry) were fed ad libitum three times daily $(0800,1300$, and $1800 \mathrm{~h})$. Two hours after feeding, uneaten feed and faecal matter from tanks holding brooders were siphoned from tank bottoms and discarded. In the growth trial, uneaten feed was manually separated from faecal matter with care and washed with distilled water before oven drying $\left(55^{\circ} \mathrm{C}\right)$. Dried uneaten feed was pooled for each replicate and weighed for calculating true feed intake. All the experimental diets were analyzed for moisture, crude protein, crude fibre and ash following the methods of Anonymous (1995) and total lipid was analyzed using the method of Folch et al. (1957). Nitrogen free extract (NFE) was calculated by difference [1000 (crude protein $\mathrm{g} \cdot \mathrm{kg}^{-1}+$ crude lipid $\mathrm{g} \cdot \mathrm{kg}^{-1}+$ crude fibre $\mathrm{g} \cdot \mathrm{kg}^{-1}+$ ash $\left.\left.\mathrm{g} \cdot \mathrm{kg}^{-1}\right)\right]$. Energy was calculated from physiological fuel values of $16.7,16.7$, and $37.7 \mathrm{KJ} \cdot \mathrm{g}^{-1}$ for NFE (carbohydrate), protein, and lipid, respectively (Garling and Wilson 1977). Live tubificid worms and oyster meat were dried before biochemical analysis using hot air oven at $55^{\circ} \mathrm{C}$ for $12 \mathrm{~h}$. Proximate composition of feeds on dry weight basis is listed in Table 2 .

At maturity, females $(3.12-3.17 \mathrm{~g})$ of respective dietary treatments were removed from the common holding tanks and housed in 500-L capacity circular fibreglass tanks ( 1 female per tank) at 25\%. Each dietary treatment had six replicates. Sex was determined based on the presence or absence of the male gonopodium; fish lacking this organ were considered to be females (Dawes 1991). The tanks contained plastic plants as shelter for free-swimming fry and were covered with netting to prevent fish from jumping out. Two males (sex ratio $1+20 \hat{)})$ were introduced into each experimental tank at 20-day intervals. Males were left in these tanks for 3 days and kept separately for the rest of the cycle. The breeders were fed their respective diets as in the common holding tanks.
The breeding trial was carried out over 6 months excluding the initial acclimation phase. Daily observations were made on fish health and fertility. In each spawning, fry production (total number of fry), gestation period (days between two successive spawnings) and weight of the newly released fry were determined. Fry were removed regularly from the breeding tank and transferred to separate tanks. At 3-5 h after spawning, the fry were fed formulated feed in the form of paste. Brood stock were weighed (to nearest $0.01 \mathrm{~g}$ ) prior to stocking and after each spawning. A few fry were sacrificed for weighing at each spawning.

For the 75-day growth trial, one-week-old fry obtained from the four parental dietary treatments were stocked into $100-\mathrm{L}$ capacity circular plastic troughs at 25 fry per trough, with three replicates for each treatment. Daily observations were made on fry survival and health. Fortnightly weighing was performed to know the growth. At the conclusion of the growth trial, mean weight gain and survival of fish in each dietary treatment were determined. Parameters analyzed were:

Feed conversion ratio $(\mathrm{FCR})=\frac{\text { dry feed intake }[\mathrm{g}]}{\text { wet weight gain }[\mathrm{g}]}$
Specific growth rate $(\mathrm{SGR})=\frac{\ln W_{\mathrm{f}}-\ln W_{\mathrm{i}}}{\mathrm{T}} \times 100$

where: $W_{\mathrm{f}}=$ mean final weight, $W_{\mathrm{i}}=$ mean initial weight, and $\mathrm{T}=$ total experimental days.

All the data were subjected to one-way ANOVA to determine significant differences among the treatments. Duncan's multiple range test (Duncan 1955) was applied to ascertain any significant differences between the treatment means. Correlation analysis was done on the weight gain of breeders against the fry yield from each spawning

Table 2

Proximate composition of experimental diets on dry matter basis

\begin{tabular}{lccc}
\hline $\begin{array}{l}\text { Chemical composition } \\
{ }^{1}\end{array}$ & Formulated feed & Oyster meat & Tubificid worms \\
\hline $\left.\mathrm{g} \cdot \mathrm{kg}^{-1}\right]$ & $946.9 \pm 8.3^{\mathrm{b}}$ & $881.1 \pm 12.8^{\mathrm{a}}$ & $885.6 \pm 7.2^{\mathrm{a}}$ \\
\hline Dry matter & $419.9 \pm 4.0^{\mathrm{a}}$ & $597.0 \pm 1.6^{\mathrm{c}}$ & $487.8 \pm 4.3^{\mathrm{b}}$ \\
Crude protein & $61.8 \pm 0.7^{\mathrm{a}}$ & $98.2 \pm 0.9^{\mathrm{b}}$ & $127.4 \pm 0.9^{\mathrm{c}}$ \\
Crude lipid & $69.4 \pm 0.6$ & na & na \\
Crude fibre & $97.8 \pm 0.6^{\mathrm{b}}$ & $113.8 \pm 0.7^{\mathrm{c}}$ & $88.1 \pm 1.2^{\mathrm{a}}$ \\
Ash & $351 \pm 2.9$ & na & na \\
NFE & $15202 \pm 6.8$ & na & na \\
Gross energy $^{2}$ & & &
\end{tabular}

\footnotetext{
${ }^{1}$ Values are means of triplicate samples; ${ }^{2}$ Nitrogen free extract calculated by difference: 1000 - (crude protein + crude lipid + crude fibre + ash $\left[\mathrm{g} \cdot \mathrm{kg}^{-1}\right] ;{ }^{3}$ Energy was calculated from physiological fuel values of $16.7,16.7$, and $37.7 \mathrm{KJ} \cdot \mathrm{g}^{-1}$ for NFE (carbohydrate), protein, and lipid, respectively; na = not analyzed; Means in the same row having different superscripts are significantly different $(P<0.05)$
} 
Table 3

Growth performance and fry yield from adult female Poecilia latipinna fed different diets in 25-\%o salt water

\begin{tabular}{lcccc}
\hline Parameter & Formulated feed & Live tubificid & Oyster meat & Mixed diet \\
\hline Initial weight $[\mathrm{g}]$ & $3.3 \pm 0.1$ & $3.4 \pm 0.3$ & $3.6 \pm 0.4$ & $3.5 \pm 0.2$ \\
Final weight $[\mathrm{g}]$ & $7.3 \pm 0.4^{\mathrm{a}}$ & $8.0 \pm 0.1^{\mathrm{b}}$ & $8.6 \pm 0.4^{\mathrm{c}}$ & $8.8 \pm 0.3^{\mathrm{c}}$ \\
Weight gain $[\mathrm{g}]$ & $4.0 \pm 0.2^{\mathrm{a}}$ & $4.5 \pm 0.2^{\mathrm{b}}$ & $5.0 \pm 0.1^{\mathrm{c}}$ & $5.4 \pm 0.2^{\mathrm{d}}$ \\
Fry yield $^{1}[\mathrm{~g}]$ & $306.7 \pm 10.1^{\mathrm{a}}$ & $341.3 \pm 28.0^{\mathrm{b}}$ & $370.7 \pm 5.0^{\mathrm{b}}$ & $460.3 \pm 14.8^{\mathrm{c}}$ \\
Correlation $^{2}[r]$ & 0.989 & 0.937 & 0.976 & 0.953 \\
$\begin{array}{l}\text { Weight of newly } \\
\text { released fry }\end{array}$ & $24 \mathrm{mg}]$ & 25 & 24 & 24 \\
\hline
\end{tabular}

${ }^{1}$ Total number of fry produced for six consecutive spawning; ${ }^{2}$ Relationships between mean weight gain of brooders and mean fry yield for seven consecutive spawning; ${ }^{3}$ Average of 50 individuals; Means in the same row having different superscripts are significantly different $(P<0.05)$.

in different salinities to delineate the relationship between the two variables. All the above-mentioned statistical analyses were performed using SPSS statistical software (Ver. 10 for Windows, SPSS, Chicago, IL, USA). Limits of significance for all critical ranges were set at $P<0.05$.

\section{RESULTS}

There were significant differences in the protein and lipid content of the feeds (Table 2). Protein and lipid content were highest in oyster meat and live tubificid worms, respectively, whereas the formulated feed had the highest moisture and lowest protein and lipid content.

Swimming, feeding and mating behaviour were normal in all treatments, and spawning was spontaneous irrespective of the diet. The duration of the first gestation period was variable but spawning occurred in all dietary treatments with 24 days of initial stocking. Thereafter, fish spawned every 28 days in all the dietary treatments. There was no significant difference in gestation period among treatments.

There were significant differences in final weight, weight gain, and fry yield of the brooders fed different experimental diets. Best results were obtained from the mixed diet, followed by the oyster and tubificid diets, and with poorest results on the formulated feed (Table 3 ). There was a significant positive correlation between fry yield and weight gain of the female brooders. Fry production increased with successive spawnings (Fig. 1). Irrespective of the dietary treatments, a few underdeveloped young ones were obtained in the first spawning in some of brooders.

All growth trials were conducted without interruption or disease problems. Significant differences were

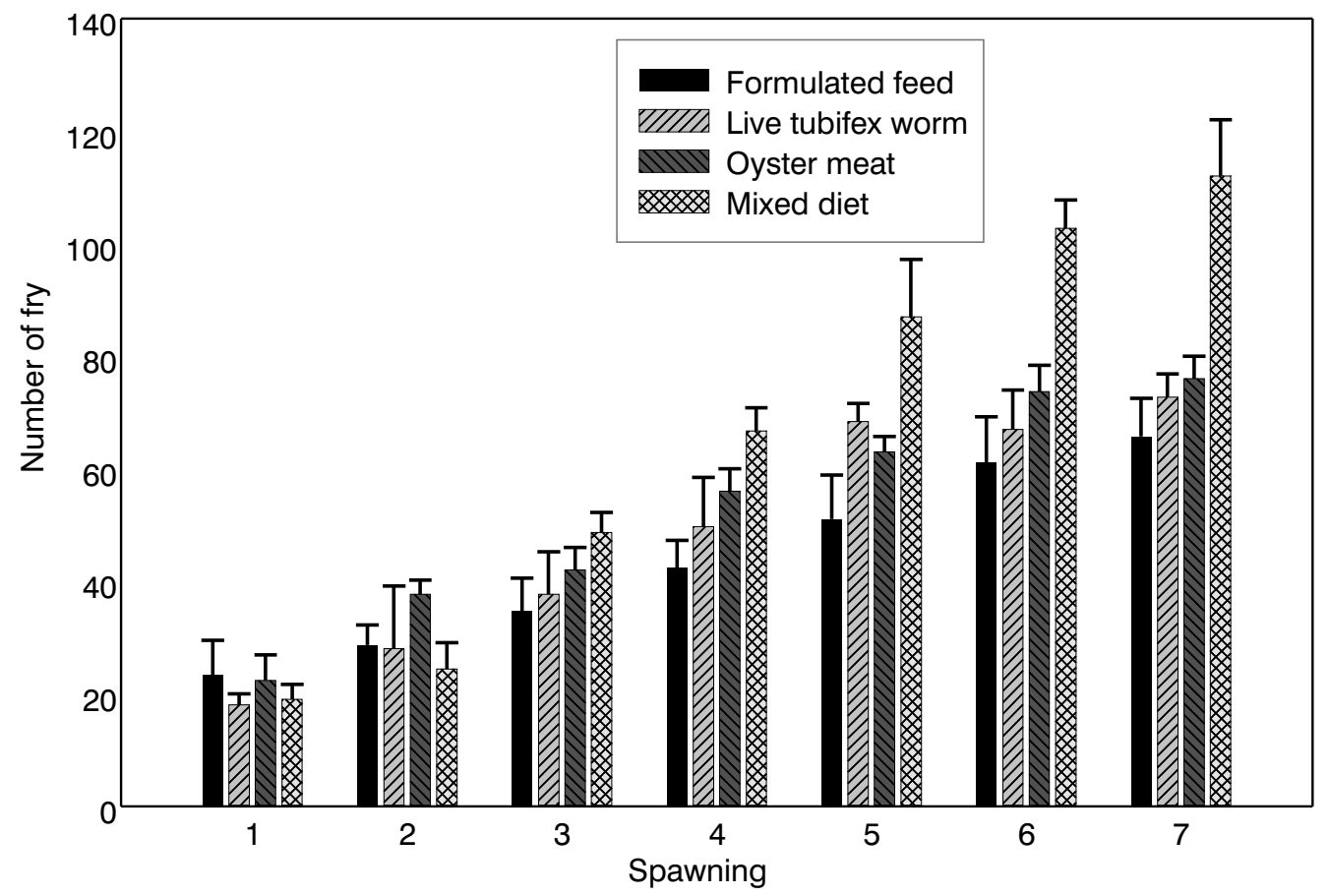

Fig. 1. Fry production of Poecilia latipinna fed different diets in $25-\%$ salt water for seven consecutive spawnings; error bars represent standard deviation of the mean $(n-3)$ 
observed for weight gain, FCR and SGR among experimental diets, with juveniles fed the mixed diet showing the best results (Table 4). There were no significant differences in survival among dietary treatments.

\section{DISCUSSION}

The successful spawning of mollies in 25-\%o salt water irrespective of the diet confirms the suitability of salt water for breeding mollies. Several investigators have demonstrated the wide salinity tolerance of poeciliid fishes such as $P$. reticulata (cf. Arai et al. 1998), Limia melanonotata (cf. Haney and Walsh 2003), P. sphenops (cf. Kristensen 1969), and P. latipinna (cf. Nordlie et al. 1992). A recent study in this laboratory by Kumaraguru vasagam et al. (2005) reported that 25-\%o salt water is optimal for breeding and rearing mollies.

Fry were produced irregularly at the start of the breeding trial and some underdeveloped fry were obtained from the first spawning. This may have been due to handling stress caused during transfer of brooders from the common holding tanks $(1000 \mathrm{~L})$ to experimental tanks $(500 \mathrm{~L})$. First spawning occurred within 8-25 days after initial stocking, likely because some of the females had embryos in advanced stages of development at the start of experiment. Similar observations were made in a previous study by Kumaraguru vasagam et al. (2005). Subsequently the gestation period was a constant 28 days throughout the experiment for all dietary treatments. This shows that diet has no influence on the gestation period of $P$. latipinna. However, systematic report on gestation period and embryonic development of mollies is limited to discuss more on this. According to Milton and Arthington (1983), the embryonic development in livebearers varies from 26 to 63 days, with temperature being the major controlling factor and photoperiod playing a minor role. Optimal temperatures for reproduction in all livebearers are reported to be between 22 and $26^{\circ} \mathrm{C}$ (Dawes 1991). In tropical country like India, temperature of this range is not a factor.
The maximum and minimum fry yields were obtained with the mixed diet (460 fry) and formulated feed (307 fry), respectively. The significant difference in fry yields with consecutive spawnings gives clear evidence of the role of diet on fry production and may be attributed to differences in proximate composition of the feeds. In fish fed the mixed diet, the formulated component probably provided the bulk of the fish's nutritional requirements, and the tubificid worm and oyster meat may have served to counteract marginal deficiencies in the formulated diet. This study also showed that none of the three diets is of itself sufficient to satisfy the nutrient requirements of the fish. A 30\% increase in fry production was recorded by Kruger et al. (2001a) in X. helleri when the daily flake diet was supplemented with live Daphnia sp. In an earlier study (Kumaraguru vasagam et al. 2005), a similar formulated feed was given to $P$. latipinna kept in salinities ranging from $0-35 \%$. The breeding and growth performance were highest at 25\% and fry yield and growth was better in fish fed mixed feed than in those fed formulated feed alone. Comparing this earlier observation with our present results clearly demonstrates the synergistic role of salinity and a nutritionally balanced diet on fry production of $P$. latipinna.

The gradual increase in fry production with each spawning may be attributed to the positive correlation between fish body weight and fry production (Tamaru et al. 2001). Milton and Arthington (1983) reported that in wild populations of swordtail, fecundity is linearly related to body size. Chong et al. (2004), in a recent study on breeding of Xiphophorus helleri, also reported a positive correlation between fecundity and parental body size. If a standard mathematical model is developed for this relationship, prediction of fry production by these livebearers could be made.

Similar to the results in breeding performance, the growth performance was also found maximum in juveniles fed a mixed dietary regime. Until now no information was available on nutrition requirement and growth of

Table 4

Growth performance of juvenile Poecilia latipinna fed different diets for 75 days in $25-\%$ on salt water ${ }^{1}$

\begin{tabular}{lcccc}
\hline Parameter & Formulated feed & $\begin{array}{c}\text { Live tubificid } \\
\text { worms }\end{array}$ & Oyster meat & Mixed feed \\
\hline Initial weight $[\mathrm{g}]$ & $0.049 \pm 0.001$ & $0.044 \pm 0.001$ & $0.047 \pm 0.002$ & $0.046 \pm 0.002$ \\
Final weight [g] & $0.738 \pm 0.037^{\mathrm{bc}}$ & $0.693 \pm 0.015^{\mathrm{b}}$ & $0.744 \pm 0.018^{\mathrm{c}}$ & $0.832 \pm 0.027^{\mathrm{d}}$ \\
Weight gain [g] & $0.690 \pm 0.036^{\mathrm{bc}}$ & $0.649 \pm 0.015^{\mathrm{b}}$ & $0.697 \pm 0.016^{\mathrm{c}}$ & $0.786 \pm 0.025^{\mathrm{d}}$ \\
Feed consumed [g] & $3.24 \pm 0.38^{\mathrm{a}}$ & $2.94 \pm 0.12^{\mathrm{b}}$ & $2.52 \pm 0.21^{\mathrm{cf}}$ & $2.29 \pm 0.12^{\mathrm{f}}$ \\
FCR $^{2}$ & $4.69 \pm 0.45^{\mathrm{b}}$ & $4.53 \pm 0.29^{\mathrm{b}}$ & $3.62 \pm 0.31^{\mathrm{a}}$ & $2.91 \pm 0.12^{\mathrm{c}}$ \\
$\mathrm{SGR}^{3}[\%]$ & $3.62 \pm 0.06^{\mathrm{a}}$ & $3.67 \pm 0.01^{\mathrm{a}}$ & $3.69 \pm 0.01^{\mathrm{a}}$ & $3.86 \pm 0.02^{\mathrm{b}}$ \\
Survival [\%] & $96.00 \pm 4.00$ & $97.33 \pm 4.62$ & $97.33 \pm 2.31$ & $98.67 \pm 2.31$ \\
\hline
\end{tabular}

${ }^{1}$ Treatment means with different superscripts within row are significantly different $(P<0.05) ;{ }^{2} \mathrm{FCR}=$ amount of feed given / amount of wet weight gain; ${ }^{3} \mathrm{SGR}=(\ln$ final wt. $-\ln$ initial wt. $) \times 100 /$ number of experimental days. 
P. latipinna under captive condition. Kruger et al. (2001b) reported that a diet should have at least $45 \%$ crude protein and $6 \%$ lipid level for better growth performance in $X$. helleri. Since both $P$. latipinna and $X$. helleri are closely related, the diet in the present study was also formulated to contain the same nutrient composition. Survival of juvenile $P$. latipinna was not significantly different among dietary treatment.

\section{CONCLUSION}

Results of this study have shown that both fry yield and growth performance of $P$. latipinna in salt water can be enhanced by adopting a mixed feeding regime as used in the present experiment. However, detailed studies on nutritional requirements of $P$. latipinna are essential to formulate most suitable formulated feeds, which will be a replacement for these fresh feeds.

\section{ACKNOWLEDGEMENT}

The first author is grateful to the authorities of the Annamalai University for the use of facilities. This research was supported in part by a research grant from the Tamilnadu State Council for Science and Technology Cell (TNSCST), Chennai, India.

\section{REFERENCES}

Anonymous 1995. Official methods of analysis. 16th edn. Association of Official Analytical Chemists, Arlington, VA.

Arai F., Shikano T., Fujio Y. 1998. An environmental factor stimulating salinity tolerance and branchial chloride cells in a euryhaline teleost Poecilia reticulata. Fisheries Science 64: 329-333.

Chong A.S.C., Ishak S.D., Osman Z., Hashim R. 2004. Effect of dietary protein level on the reproductive performance of female swordtails Xiphophorus helleri (Poeciliidae). Aquaculture 234: 381-392.

Dawes J.A. 1991. Livebearing fishes: A guide to their aquarium care, biology and classification. Blandford Publications, London.

De Silva S.S., Anderson T.A. 1995. Fish nutrition in aquaculture. Chapman and Hall, London.

Duncan D.B. 1955. Multiple range and multiple F-tests. Biometrics 11: 1-42.

Fernando A.A., Phang V.P.E., Chan S.Y. 1991. Diets and feeding regimes of poeciliid fishes in Singapore. Asian Fisheries Science 4: 99-107.

Folch J., Lees M., Sloane-Stanley G.H. 1957. A simple method for the isolation and purification of total lipides from animal tissues. Journal of Biological Chemistry 226: 497-509.

Garling jr. D.L., Wilson R.P. 1977. Effect of dietary carbohydrates-to-lipid ratio on growth and body composition of fingerling channel catfish. Progressive Fish-Culturist 39: 43-47.

Ghosh A., Mahapatra B.K., Datta N.C. 2003. Ornamental fish farming-successful small scale business in India. Aquaculture Asia 8 (3): 14-16.

Haney D.C., Walsh S.J. 2003. Influence of salinity and temperature on the physiology of Limia melanonotata
(Cyprinodontiformes: Poeciliidae): a search for abiotic factors limiting insular distribution in Hispaniola. Caribbean Journal Science 39: 327-337.

Hislop J.R.G., Robb A.P., Gauld J.A. 1978. Observations on effects of feeding level on growth and reproduction in haddock, Melanogrammus aeglefinus (L.) in captivity. Journal of Fish Biology 13: 85-98.

Kristensen I. 1969. Competition in three cyprinodont fish species in the Netherlands Antilles. Studies of the Fauna of Curacao and Other Caribbean Islands 32: 82-101.

Kruger D.P., Britz P.J., Sales J. 2001a. The influence of livefeed supplementation on growth and reproductive performance of swordtail (Xiphophorus helleri Heckel, 1848) broodstock. Aquarium Science and Conservation 3: 265-273.

Kruger D.P., Britz P.J., Sales J. 2001b. Influence of varying dietary protein content at three lipid concentrations on growth characteristics of juvenile swordtails (Xiphophorus helleri Heckel, 1848). Aquarium Science and Conservation 3: 275-280.

Kumaraguru vasagam K.P., Rajagopal S., Balasubramanian T. 2005. Effect of salinity on gestation period, fry production, and growth performance of the sailfin molly (Poecilia latipinna Lesueur) in captivity. The Israeli Journal of Aquaculture (Bamidgeh) 57: 147-152.

Mahapatra B.K., Ghosh A., Datta, N.C. 2000. Breeding and rearing of ornamental fishes, guppy, Poecilia reticulata (Peter) and goldfish, Carassius auratus (Linnaeus) for prospective entrepreneurship development. Green Technology 3: 26-33.

Mihelakakis A., Kitajima C. 1994. Salinity tolerance of the flounder, Paralichthys olivaceus larvae with growth. Journal Faculty Agriculture 39: 25-33.

Milton D.A., Arthington A.H. 1983. Reproductive biology of Gambusia affinis holbrooki Baird and Girard, Xiphophorus helleri (Gunther) and X. maculatus (Heckel) (Pisces; Poeciliidae) in Queensland, Australia. Journal of Fish Biology 23: 23-41.

Nordlie F.G., Mirandi A. 1996. Salinity relationships in a freshwater population of eastern mosquitofish. Journal of Fish Biology 49: 1226-1232.

Nordlie F.G., Haney D.C., Walsh S.J. 1992. Comparisons of salinity tolerances and osmotic regulatory capabilities in populations of sailfin molly (Poecilia latipinna) from brackish and freshwaters. Copeia 1992: 741-746.

Ramachandran A. 2002. Manual on breeding, farming \& management of ornamental fishes. School of Industrial Fisheries, Cochin, India.

Sampaio L.A., Bianchini A. 2002. Salinity effects on osmoregulation and growth of the euryhaline flounder Paralichthys orbignyanus. Journal of Experimental Marine Biology and Ecology 269: 187- 196.

Springate J.R.C., Bromage N.R., Cumaranatunga P.R.T. 1985. The effects of different ration on fry production and egg quality in the rainbow trout (Salmo gairdneri). Pp. 371-393. In: Cowey C.B., Mackie A.M., Bell J.G. (eds.) Nutrition and Feeding of Fish. Academic Press, London.

Strickland J.D.H., Parsons T.R. 1972. Inorganic micronutrients in sea water. Pp. 167-310. In: Stevenson J. (ed.) A practical handbook of seawater analysis. Fisheries Research Board of Canada, Ottawa. 
Tamaru C.S., Cole B., Bailey R., Brown C., Ako, H. 2001. A manual for commercial production of the swordtail, Xiphophorus helleri. Center for Tropical and Subtropical Aquaculture (Publication No. 128), University of Hawaii Sea Grant Extension Service, Honolulu.

Tandler A., Helps S. 1985. The effects of photoperiod and water exchange rate on growth and survival of gilthead sea bream (Sparus aurata, Linnaeus; Sparidae) from hatching to metamorphosis in mass rearing systems. Aquaculture 48: 71- 82 .

Townsend T.J., Wootton R.J. 1984. Effects of food supply on the reproduction of the convict cichlid, Cichlasoma nigrofasciatum. Journal of Fish Biology 24: 91-104.

Watanabe T. 1985. Importance of the study of broodstock nutrition for further development of aquaculture. Pp. 395-414.
In: Cowey C.B., Mackie A.M., Bell J.G. (eds.) Nutrition and Feeding of Fish. Academic Press, London.

Whitern W.A. 1983. Livebearers. Tropical Fish Hobbyist Publications, Neptune City, NJ.

Wootton R.J. 1973. The effect of size of food ration on egg production in the female three-spined stickleback, Gasterosteus aculeatus L. Journal of Fish Biology 5: 89-96.

Received: 16 April 2007

Accepted: 12 June 2007

Published electronically: 15 July 2007 